\title{
JOURNAL

\section{The impact of petrol price movements on South African inflation}

\section{Logan Rangasamy}

South African Reserve Bank, International Economic Relations and Policy Department, PO Box 427, Pretoria 0001, South Africa; North-West University, Graduate School of Business and Trade Niche Research Area, Private Bag X6001, Mmabatho, 2520, South Africa.

\section{Abstract}

This paper analyses the impact of petrol price movements on inflation outcomes in South Africa since the mid-1970s. The results show that, over time, the direct contribution of petrol inflation to headline inflation has not only increased, but has also exceeded its weight in the consumer price index. In addition, Granger causality tests and the autoregressive distributed lag approach to co-integration testing reveal that petrol prices have an important bearing on the prices of other (non-petrol) commodities in the economy. The results essentially show that petrol price increases had an important bearing on inflation outcomes in South Africa. This implies that petrol price movements warrant special attention in policy
\end{abstract}

formulation and implementation in South Africa if inflation outcomes were to be kept in check.

Keywords: commodity prices, energy prices, inflation, core inflation

\footnotetext{
* Corresponding author: Tel: +27 123134410

Email: Logan.Rangasamy@resbank.co.za
} 


\section{Introduction}

South African petrol prices are adjusted monthly on the basis of an import parity pricing principle. What is the effect of these adjustments on inflation? This paper attempts to shed some light on this question by analysing how fuel price increases and decreases have affected inflation outcomes in South Africa since the mid-1970s.

The empirical literature has tended to focus on the pass-through effects of oil price shocks on macroeconomic developments. However, oil is a raw commodity and its impact on macroeconomic developments occurs through fuel (petrol) price movements. There are essentially two reasons why the focus has been on the impact of oil prices rather than petroleum prices. Firstly, there is a strong correlation between oil prices and petroleum prices - particularly in the absence of fuel subsidies - and in this case, oil price movements serve as a good proxy for fuel price movements. Secondly, oil prices are more readily available, thus facilitating easier cross-country comparative research.

In a seminal research article, Hamilton (1983) showed a strong negative relationship between oil price changes and real economic activity in the United States of America. While this perception enjoyed increasing support (Gisser and Goodwin, 1986; Burbidge \& Harrison, 1984; Bruno \& Sachs, 1985), it also became evident that there was an asymmetric relationship between oil price changes and economic activity in the USA (Mork, 1989) as well as in OECD countries (Mork et al., 1994). It has been argued that this asymmetry could be due to producers being reluctant to change prices with oil price movements since this could involve increased operational costs (Lilien, 1982; Hamilton, 1988) or to monetary policy responses (Bernanke et al., 1997; Barsky and Kilian, 2001). According to Bernanke et al. (1997), while restrictive monetary policy has been used to keep inflationary pressures in check, oil price declines have in general not necessarily been followed by expansionary policies. The relationship between oil prices and inflation has also received much attention in the empirical literature. In general, the evidence for advanced countries shows that the influence of oil price shocks on inflation outcomes have declined over time (Hooker, 2002). Leblanc and Chinn (2004) also assert that oil price shocks have a modest impact on US inflation. Clark and Terry (2010) also find support for this result with the effect mainly being ascribed to a pronounced reduction in the passthrough of energy price inflation to core inflation (conventionally calculated headline inflation less food and energy inflation) in the USA since the mid1970s. Their results indicate that, by 1985 , pass through from energy to core inflation in the USA had declined to zero, implying that energy price shocks have not exerted a strong influence on US monetary policy during the last three decades. Blanchard and Gali (2010) also found evidence of declining pass-through effects from energy prices to inflation for G-7 countries particularly since the mid1980s. Killian (2008) shows that the 2002-03 oil price shock had a negligible impact on inflation in the G-7 countries.

Chen (2009) used a state space approach and finds that the time-varying oil price pass-through coefficients for a group of 19 industrial countries have declined over time. Álvarez et al. (2011) argued that this decline is due to a more active anti-inflationary monetary policy stance, the appreciation of the nominal exchange rate and higher trade openness that have characterised macroeconomic developments in many countries over time. According to Trehan (2005), the better anchoring of inflation expectations also partly accounts for the weakening in the relationship between oil prices and inflation. De Gregorio et al. (2008) employed Phillips curve and rolling vector auto-regressive estimates to show that the decline in pass-through has been more pronounced in advanced than in emerging countries. They attributed this decline to a reduction in the oil intensity, the prevalence of a more favourable inflation environment and a reduction in the exchange rate pass-through which has characterised macroeconomic developments in advanced economies in recent times. Examining data for both advanced and developing countries, Cecchetti and Moessner (2008) found that, in the period preceding the commodity price hike of 2008, core inflation did not revert to headline inflation. This implies that oil price shocks have had a limited impact on the build-up of inflationary pressures. Álvarez et al. (2011) found that, while higher household spending on petroleum products has resulted in an increase in the direct inflationary effects, the indirect effects have declined over time in Spain. However, using country-specific vector autoregressive models and panel estimations, Zoli (2009) found that international commodity price shocks did have a significant impact on domestic inflation outcomes for a group of eighteen European emerging economies.

Habermeier et al. (2009) used panel estimations to show that commodity prices have a strong bearing on inflation outcomes in developing and emerging economies, mainly as a result of commodity price increases being passed through to other noncommodity prices in the economy. This is referred to as second round price effects in the economic literature and occurs when petrol price increases result in rises in input or production costs which result in a 
more generalised price increase in the economy. According to Rigobón (2010), the impact of commodity price shocks on micro price data varies across countries, with sectorial characteristics mainly accounting for the magnitude of the pass-through price effects across goods and services. Pedersen (2011) used structural VAR models to analyse the propagation of food and energy price shocks in 46 developed and developing countries for the period 1999-2010. In general, he found that the propagation effect of food price shocks exceeded that of energy price shocks, with the effects being more prominent in emerging economies because of the larger weight of food and energy in the consumption basket there. The IMF (2008) also found that the passthrough effects from international commodity prices to domestic prices were higher for emerging economies. According to the IMF (2008), fuel intensity and pre-existing inflation levels have a bearing on how countries respond to commodity price shocks.

The paper is structured as follows. Section 2 provides a brief overview of the empirical literature on the macroeconomic impacts of fuel price changes. The next section highlights how fuel prices have evolved in South Africa over the last three and a half decades. Section 4 documents the direct inflationary impact of fuel price increases while the indirect impact of fuel price increases is the main focus of attention in section 5 . The penultimate section highlights some policy implications and areas for further research and section 7 concludes.

\section{A brief overview of fuel price movements}

Since the 1950s South African fuel prices have been based on the import parity pricing principle (Competition Tribunal, 2006), which essentially links the domestic price of a product to the imported cost of the product. In this case, one of the main objectives is to ensure that domestic prices are in sync with international price developments and hence do not lead to a misallocation of domestic resources. The import parity price of petrol was based on the inbond landed cost (IBLC) formula. This formula was implemented in the 1950s and was used to calculate the retail price of fuel up until April 2003. It distinguished between two groups of factors that had a bearing on the fuel price. Firstly, those that reflected the impact of international developments and, secondly, other domestic influences. The international price element in the formula was calculated by considering the prevailing petroleum prices on the global market and the costs associated with the transportation of these products to South Africa.

Domestic influences included taxes, levies and margins that were added to the international price element to give the retail pump price of fuel. In April
2003, the basic fuel price (BFP) replaced the international component in the IBLC formula. The BFP is also based on the import parity pricing principle. The main motivation for the change, however, was to provide a more accurate estimate of the international price of petroleum products. This was based on the daily spot prices quoted in international markets rather than on the prices at specific refineries at the middle of the preceding month as was the case with the IBLC formula. Figure 1 depicts the movements of petrol prices and non-petrol prices in South Africa since 1975. These price movements are based on the changes in the respective components in the consumer price index (CPI), which is an aggregation of the price series of goods and services consumed by the average household. The inflation rate is given by year-on-year change in the CPI. Petrol price movements refer to changes in the petrol price index in the CPI, while non-petrol price movements reflect the aggregation of the price movements of all the other goods and services excluding petrol contained in the CPI basket. The non-petrol price index is calculated as the aggregate CPI excluding petrol price index. The core inflation index is: $\rho_{t}^{n f}=$ $\frac{\rho_{t}^{h}-\rho_{t}^{f} \cdot \omega_{t}^{f}}{\omega_{t}^{n f}}$; where, $\rho_{t}^{h}, \rho_{t}^{f}, \rho_{t}^{n f}$ represent the price index of headline, petrol and non-petrol respectively for time t. $\omega_{t}^{f}$ and $\omega_{t}^{n f}$ represent the weights of petrol and non-petrol inflation and $\omega_{t}^{n f}=1-\omega_{t}^{f}$.

There are three broad observations that can be made from Figure 1. Firstly, petrol prices tracked non-petrol price movements quite closely during the period 1975 to the end of the 1980s and also between 2000 and 2005. Between 1990 and 2000 non-petrol price increases in general exceeded that of petrol prices. Finally, since 2005 petrol prices have risen exponentially, although more recently there has been a significant drop. Figure 2a depicts the contribution of domestic and international factors to the petrol price in cents per litre. It indicates that, while the contribution of both factors to the domestic fuel price increased, the influence of international factors as depicted by BFP, became more dominant over time. In the 1990s international influences as reflected by the percentage share of BFP in the petrol price, averaged between 35 and 40 percent (Figure 2a); Data on the contribution of international factors (BFP) is only available from 1986 and hence this analysis is restricted to the period beginning 1990 while thee Hodrik-Prescott filter is used to determine the trend. By the end of 2013, international factors accounted for approximately 60 percent of the petrol price. However, given the drop in international oil prices, the contribution declined to around 50 percent by the end of 2015 . Further, the importance of international factors in 
domestic petrol price movements is evident by the strong correlation between South African petrol prices and the BFP, particularly since the early 2000 s when there was a significant rise in the share of the BFP in the petrol price (Figure 2c) - correlation coefficient is based on a recursive estimate beginning January 1986.

International factors influence domestic petrol prices through two channels; either through changes in international prices (i.e. international product prices or costs) and through exchange rate changes. Figure 3 shows the BFP in both rand (ZAR) and dollar terms (USD) to draw attention to the impact of exchange rate changes on the BFP. For much of the period since 2000, the increase in the BFP is attributed to rises in international product prices and costs as reflected by the close co-movement in the two series (BFP in ZAR and BFP in USD). During the mid-to-late 2000s the appreciation of the rand dampened the increase in domestic prices.

More recently, however, the depreciation of the currency put significant upward pressure on domestic petrol prices. For example, between January 2011 and January 2014, the ZAR depreciated by 57 percent, while international product prices in terms of BFP declined by about 18 percent during the same period. Essentially, therefore, if the rand maintained its January 2011 value, the domestic fuel price would be approximately 40 percent lower in ZAR. Given the current speculation that some emerging market currencies like ZAR are likely to remain under pressure as a result of the tightening conditions in global financial markets, the exchange rate is likely to be a major factor influencing future petrol price developments.

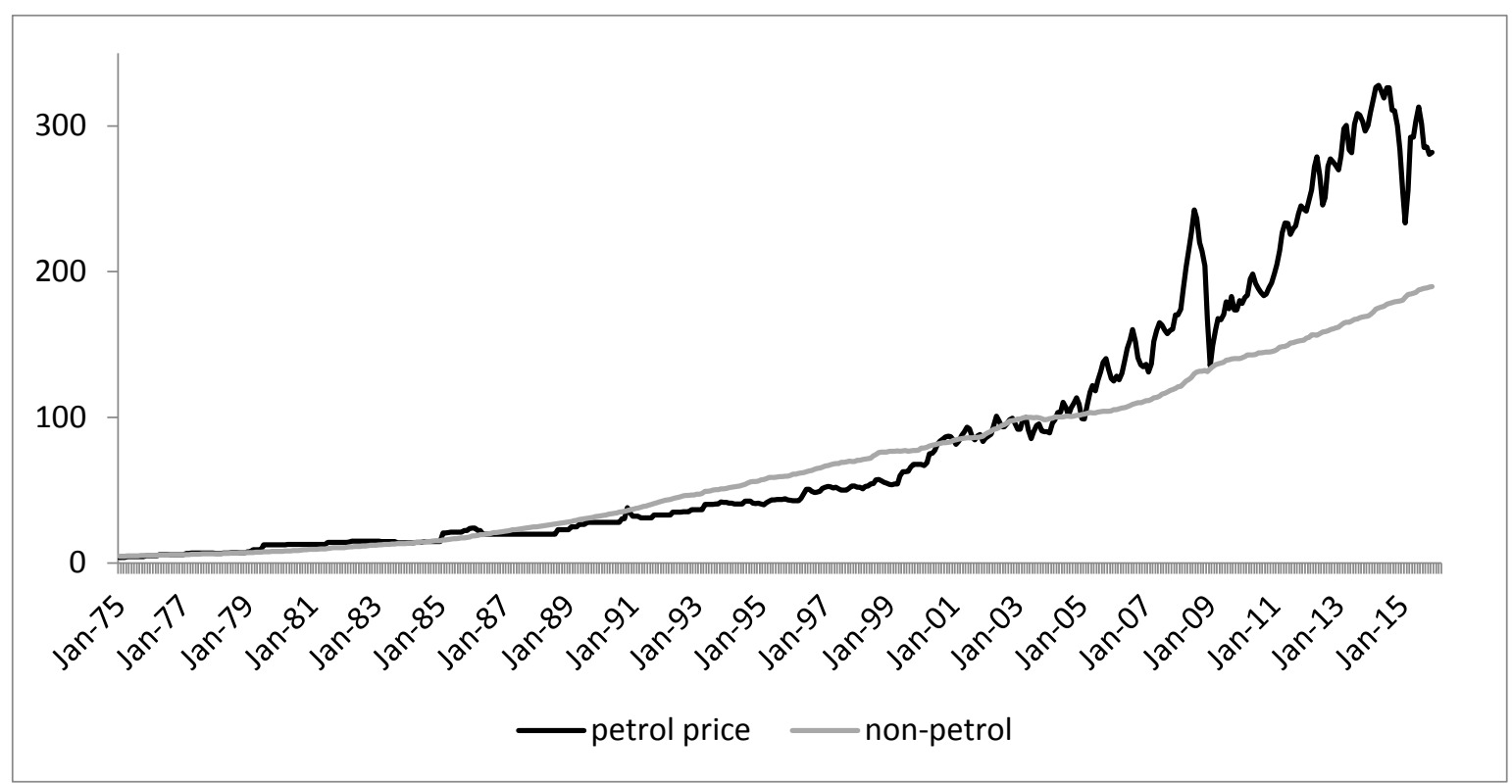

Figure 1: Petrol price movements vis-à-vis price movements of other goods and services for period January 1975 to December 2015 (April $2003=100$ ).

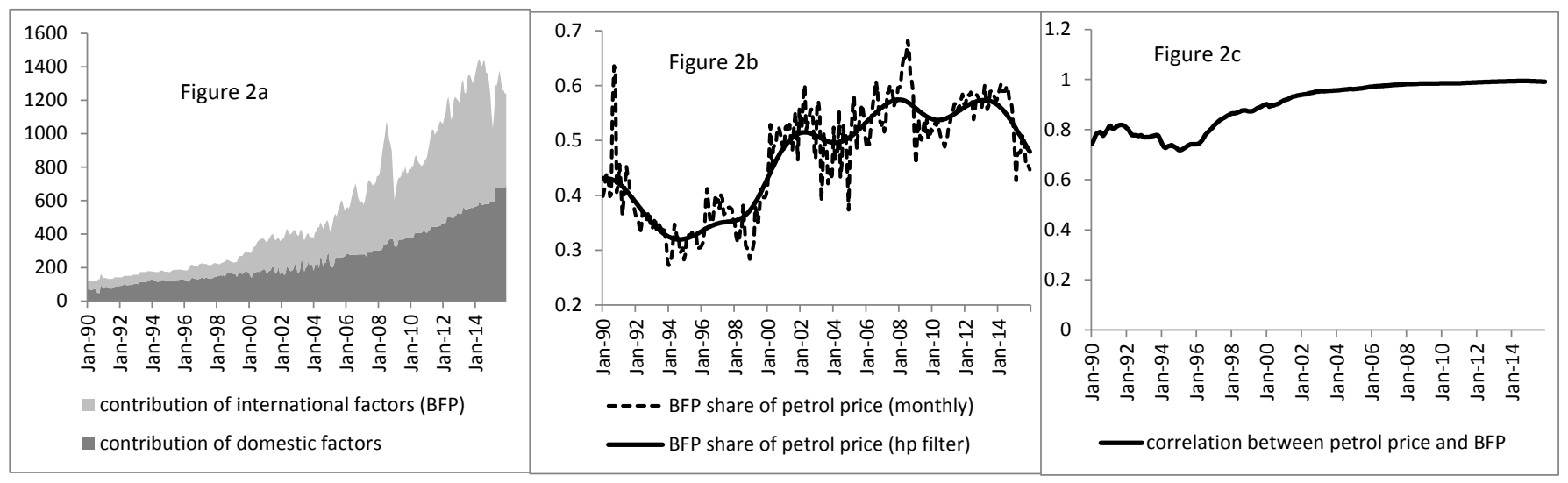

Figure 2: (a) Influence of domestic and international factors on fuel price; (b) trend movement in BFP; (c) correlation between BFP and petrol price. 


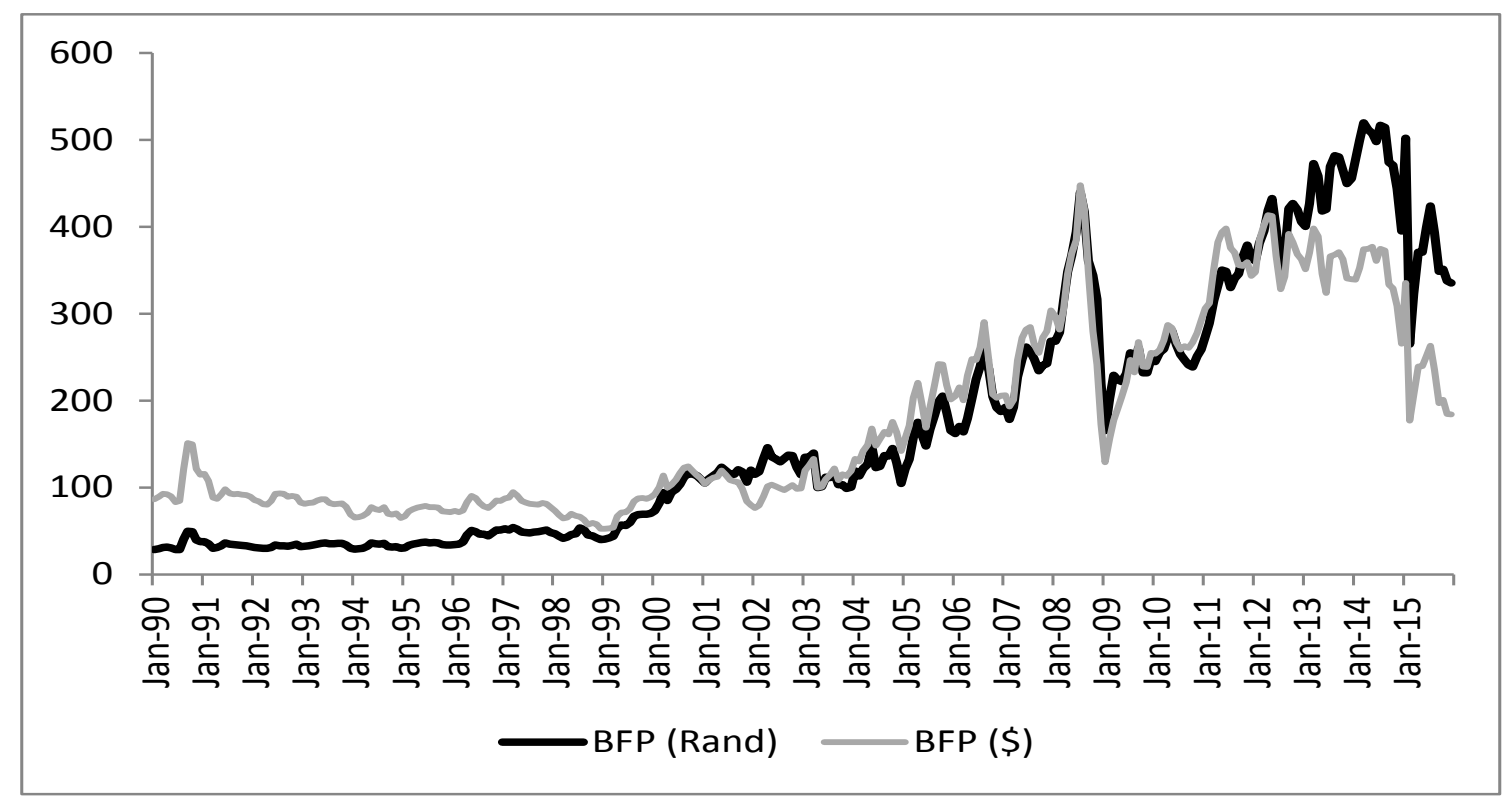

Figure 3: Impact of international prices and exchange rate changes on the fuel price in South Africa.

Table 1: Inflation rates and contribution of petrol prices to headline inflation, where calculations were based on information from Statistics South Africa.

\begin{tabular}{|c|c|c|c|c|}
\hline Variable & $1980-89$ & $1990-99$ & 2000-09 & $2010-15$ \\
\hline (a) Headline inflation ${ }^{1}$ & 14.6 & 9.9 & 6.1 & 5.2 \\
\hline (b) Petrol inflation ${ }^{2}$ & 11.2 & 9.0 & 11.9 & 10.0 \\
\hline (c) Weight of petrol in $\mathrm{CPI}^{3}$ & 0.040 & 0.034 & 0.047 & 0.051 \\
\hline $\begin{array}{l}\text { (d) Contribution of petrol inflation to head } \\
\text { line inflation }\end{array}$ & 0.4 & 0.3 & 0.6 & 0.5 \\
\hline $\begin{array}{l}\text { (e) Contribution of petrol inflation as share of } \\
\text { headline inflation }{ }^{5}\end{array}$ & 0.03 & 0.04 & 0.10 & 0.10 \\
\hline $\begin{array}{l}\text { (f) Contribution of petrol inflation relative to } \\
\text { its weight in the } \mathrm{CPI}^{6}\end{array}$ & 0.75 & 1.18 & 2.13 & 1.96 \\
\hline \multicolumn{5}{|c|}{$\begin{array}{l}\text { Notes: } \\
\text { 1. Year-on-year change in the headline CPI. } \\
\text { 2. Year-on-year change in the petrol price index of the CPI. } \\
\text { 3. The average weight of the petrol prices in the CPI for the specified period. } \\
\text { 4. The contribution of petrol prices to headline inflation in percentage points }(d=c * b) \text {. } \\
\text { 5. The contribution of petrol price inflation to headline inflation }(e=(d) /(a)) \text {. } \\
\text { 6. The contribution of petrol inflation expressed as a ratio of its weight in the CPI basket }[f=(e) /(c)] \text {. }\end{array}$} \\
\hline
\end{tabular}

3. The inflationary impact of fuel price increases Inflation refers to the general increase in the prices of goods and services in the economy. Price increases reduce the purchasing power of money that in turn has an adverse impact on consumers' welfare. The primary measure of overall price increases in the economy is encapsulated by the inflation rate. The inflation rate reflects the annualised percentage change in the consumer price index, which tracks the rate of change in the prices of goods (such as petrol) and services purchased by consumers. The impact of petrol price changes on inflation occurs directly by virtue of petrol being part of the CPI basket and indirectly through its impact on the prices of other non-petrol products that use energy products in the $\mathrm{CPI}$.

There was a consistent decline in aggregate inflation from an average rate of approximately 15 percent in the 1980s to below 6 percent in the period January 2010 to December 2015 (Table 1).

Petrol price inflation was in double digit territory for most of this period with the exception of the nineties when it averaged 9 percent. The weight of petrol products in the CPI has increased - albeit 
marginally - from 4 percent in the 1980s to an average of 5 percent during the post-financial crisis period. This has resulted in the direct contribution of fuel prices to headline inflation steadily increasing over time and averaging 0.5 percentage points for the period January 2010 to December 2015 (Table 2 row (d)). The contribution as a percentage of headline inflation increased from 3 percent in the 1980 s to an average of 10 percent in the post-financial crisis period because of the steady decline in headline inflation over the last three and half decades, despite a small contribution in absolute terms.

The significance of this development can be gauged by comparing this contribution (i.e. the contribution of petrol price increases to headline inflation) to the weight of petrol prices in the CPI. A neutral impact exists, in general, when the contribution of a product price to headline inflation is in line with its weight in the CPI. In the 1980s, the contribution of petrol price movements to headline inflation was lower than its weight in the CPI. Since then petrol price increases played a much larger role in headline inflation with the contribution of petrol price increases to headline inflation exceeding its weight in the CPI (Table 1, row (f)). More specifically, its contribution to headline inflation increased from 1.2 times its weight in the CPI during the 1990s to approximately double its weight in the post 2000 era.

Thus, in summary, while the trend of headline inflation was downwards, petrol inflation remained in double digit territory, with the result that the direct contribution of petrol price inflation to headline inflation steadily increased over time. As pointed out earlier, petrol price changes can also have an indirect impact on inflation. This occurs when petrol price movements influence overall inflation through its impact on the price of non-petrol products in the CPI. This effect occurs through higher input costs and through adverse impacts on inflationary expectations, which in turn feed through into higher wages, product prices and eventually into overall inflation.

What is the impact of petrol prices on other (nonpetrol) prices in South Africa? In this regard, a good starting point is to consider the causal link between
South African petrol price inflation and non-petrol price inflation. A bivariate vector autoregressive (VAR) model comprising petrol inflation (Pet) and non-petrol (NonPet) inflation and the Toda and Yamamoto (1995) Granger Causality test is used to ascertain the causal link between the variables. The major advantage of the Toda and Yamamoto (1995) Granger Causality test is to allow a test for causality even when some or all of the time-series data are non-stationary. The bivariate VAR model is given by Equations 1 and 2 .

$$
\text { Pet }_{t}=\alpha_{1}+\sum_{i=1}^{h+d} \beta_{1 i} \Delta \text { Pet }_{t-i}+\sum_{i=1}^{l+d} \gamma_{1 j} \text { NonPet }_{t-j}+\mu_{1 t}
$$

$$
\text { NonPet }_{t}=\alpha_{2}+\sum_{i=1}^{h+d} \beta_{2 i} \Delta \text { Pet }_{t-i}+\sum_{i=1}^{l+d} \gamma_{2 j} \text { Pet }_{t-j}+\mu_{2 t}
$$

where $d$ is the maximal order of integration of the variables in the system, $h$ and $l$ are the optimal lag length of Pet and NonPet and $\mu_{1 t}$ and $\mu_{2 t}$ are the white noise error terms. The two Granger causality tests of interest are:

Test 1: $H_{0}:$ Pet $_{t}$ does not granger-cause NonPet $_{t}$ if $\gamma_{2 j}=0$ against the alternative hypothesis, $H_{1}$ : Pet $t_{t}$ does granger-cause NonPet $t_{t}$ if $\gamma_{2 j} \neq 0$

Test 2: $H_{0}:$ NonPet $_{t}$ does not granger-cause Pet $_{t}$ if $\gamma_{1 j}=0$ against the alternative hypothesis $H_{1}$ : NonPet $t_{t}$ does granger-cause Pet $_{t}$ if $\gamma_{1 j} \neq 0$

Table 2 reports the unit root tests of the variables using the augmented Dickey-Fuller test. The data is of monthly frequency for the period January 1976 to December 2015. The results depict a mix of stationary and nonstationary variables thus supporting the use of the Toda and Yamamoto Granger Causality test.

Table 2: Results of unit root test.

\begin{tabular}{lcccc}
\hline \multicolumn{1}{c}{ Variable } & Constant and/or trend & Level & First difference & Inference \\
\hline Pet (petrol inflation) & Constant & $-6.31^{*}$ & $-12.29^{*}$ & $\mathrm{I}(0)$ \\
Pet (petrol inflation) & Constant and trend & $-6.25^{*}$ & $-12.24^{*}$ & $\mathrm{I}(0)$ \\
NonPet (non-petrol inflation) & Constant & -1.54 & $-7.03^{*}$ & $\mathrm{I}(1)$ \\
NonPet (non-petrol inflation) & Constant and trend & -2.70 & $-7.03^{*}$ & $\mathrm{I}(1)$ \\
\hline Note: * denotes significance at 5 percent level. & & & \\
\hline
\end{tabular}


Table 3: Toda and Yamamoto Granger causality test (Jan 1976 to Dec 2015)

(StatsSA and author's calculations).

\begin{tabular}{cccc}
\hline Causality from & Null hypothesis & $\begin{array}{c}\text { Chi-square statistic } \\
\text { (Probability) }\end{array}$ & Conclusion \\
\hline Petrol inflation to non-petrol inflation & No causality exists & $28.44(0.001)$ & Reject hypothesis \\
Non-petrol inflation to petrol inflation & No causality exists & $15.23(0.293)$ & Cannot reject hypothesis \\
\hline
\end{tabular}

The results in Table 3 indicate that there is unidirectional causality from petrol to non-petrol prices. There are no causal effects from non-petrol to petrol prices. This is in line with the results presented in Section 3, which showed that it was international factors rather than domestic factors driving South African fuel price changes.

In summary, petrol price increases have a direct impact on headline inflation by virtue of its share in the CPI basket. In addition, the granger causality tests show that petrol price increases also have indirect effects on headline inflation by virtue of its impact on other (non-petrol) prices. The next section will employ econometric techniques to examine the total impact of petrol price movements on headline inflation.

\section{Econometric analysis of petrol price ef- fects on inflation}

A better understanding of the relationship between petrol prices and inflation can be gauged by considering a generalised Phillips curve augmented to include petrol price movements and expressed as in Equation 3.

$$
\text { Infl }_{t}=\beta_{0}+\beta_{1} \text { Gap }_{t}+\beta_{2} \text { Petrol }_{t}+D+\varepsilon_{t}
$$

where Infl = headline inflation, $\beta_{0}=$ constant, Gap = output gap, Petrol $=$ petrol inflation, $\varepsilon=$ white noise error term; $\mathrm{D}=$ dummy for a structural break (The Bai-Perron test corroborates the existence of a structural break in 1995Q3 (F-Statistic $=12.91$ and significant at the 5 percent level).

The auto regressive distributed lag (ARDL) method of co-integration developed by Pesaran and Pesaran (1997); Pesaran and Shin (1999); and Pesaran et al. $(2000 ; 2001)$ is used in the estimation of Equation 3. As is now well documented in the empirical literature, the ARDL approach has some advantages over other co-integration methods. Firstly, the methodology can be used with both $\mathrm{I}(0)$ and I(1) variables. Secondly, the ARDL approach can handle small sample properties. Finally, the estimation procedure can be used even if the explanatory variables were endogenous. Before undertaking the estimation of the ARDL model, a necessary prior step is to apply the Bounds test to establish if there is a long-run relationship among the variables included in the model. The ARDL model used for estimating the petrol price effects on inflation is given by Equation 4.

$$
\begin{aligned}
& \text { Infl }_{t}=\alpha_{0}+\alpha_{1} \sum_{i=1}^{n} \Delta \text { Gap }_{t-i}+\alpha_{2} \sum_{i=1}^{n} \Delta \text { Petrol }_{t-i} \\
& +\alpha_{3} \sum_{i=1}^{n} \Delta D_{t-i}+\beta_{1} \text { Gap }_{t-1}+\beta_{2} \text { Petrol }_{t-1}+\beta_{3} D_{t-1}+\mu_{t}
\end{aligned}
$$

where $\alpha_{0}=$ constant, $\mu_{t}=$ white noise error term and the error correction dynamics being captured by the summation sign while the latter part of Equation 4 reflects the long-run relationship. The Akaike information criterion is used to identify the optimum lag in the model. The Wald (F-statistics) derived from Equation 4 is a critical part of the ARDL procedure and is used to establish if there is a long-run relationship among the series. The null and alternative hypotheses for the Wald tests are given by Equations 5 and 6.

$$
H_{0}: \beta_{1}=\beta_{2}=\beta_{3}=0
$$

$H_{a}: \beta_{1}=\beta_{2}=\beta_{3} \neq 0$

The computed $F$-test statistics are compared with the critical values provided by Pesaran et al. (2001) and Narayan (2005) for the hypothesis tests. In terms of this procedure, the lower bound critical values assume that the explanatory variables are integrated of order one and hence if the computed $F$ statistic is less than the lower bound value, the null cannot be rejected. On the other hand, if the computed $F$-statistics exceeds the upper bound value, then there is a long-run relationship among the variables. Finally, if the computed $F$-statistics lies between the lower bound and upper bound, the test is for a long-run association among the variables is inconclusive. On finding evidence of a long-run relationship between variables, one can proceed to estimate the ARDL model, by first estimating the longrun coefficient as in Equation 7. 


$$
\begin{aligned}
& \text { Infl }_{t}=\alpha_{0}+\alpha_{1} \sum_{i=1}^{n} \text { Gap }_{t-i}+\alpha_{2} \sum_{i=1}^{n} \text { Petrol }_{t-i} \\
& +\alpha_{2} \sum_{i=1}^{n} D_{t-i}+\mu_{t}
\end{aligned}
$$

Finally, the short-run dynamic parameters may be obtained by estimating the vector error correction model given by Equation 8 .

$$
\begin{aligned}
& \Delta \operatorname{Infl}_{t}=\lambda_{0}+\beta_{1} \sum_{i=1}^{n} \Delta \operatorname{Gap}_{t-i}+\beta_{2} \sum_{i=1}^{n} \Delta \text { Petrol }_{t-i} \\
& +\beta_{2} \sum_{i=1}^{n} \Delta D_{t-i}+n E C T_{t-1}+\mu_{t}
\end{aligned}
$$

where $\beta$ reflects the short-run dynamic coefficients and the speed of adjustment needed to restore equilibrium over the long run is given by $\eta$.

\subsection{Empirical results and discussion}

The estimates are done on quarterly data, given that the output gap measure is based on real gross domestic product which is only available at quarterly. The empirical analysis starts by assessing the stationarity properties of the variables by applying the augmented Dickey-Fuller unit root test. The 'breakpoint unit root test' is used to account for the structural break in the data. The unit root test results are presented in Table 4. They show that the model contains a mix of stationary and nonstationary variables which makes the ARDL model suitable for the analysis of the pass-through effects of petrol price movements to inflation.

As mentioned earlier, the first step is to use the bounds test to determine if there is a long-run relationship among the variables. Table 5 reflects the $F$ statistics applied to Equation 4. The lag order was chosen using the Akaike information criterion. The null hypothesis of no co-integration in the model is rejected at the 1 percent level of significance, thus supporting the hypothesis of a long-run relationship among the variables. After having established that there is a valid long-run relationship among the variables, the ARDL method was applied, to estimate the long-run and short-run coefficients.

Panel A of Table 6 indicates that all the independent variables have a significant impact on headline inflation in the long-run. All the coefficients are significant at the 5 percent level with their respective signs conforming to theoretical expectations. More specifically, a 10 percent increase in petrol inflation (petrol) results in a 1.2 percent increase in headline inflation. The coefficient on the output gap indicates that a closing of the output gap puts upward pressure on headline inflation. The dummy variable is highly significant (at the 1 percent level) with a negative influence on headline inflation. The dummy variable could in part be capturing the influence of the opening of the South African economy in the democratic era. With the advent to democracy in April 1994, the process of globalisation

Table 4: Results of unit Root test calculations using Eviews.

\begin{tabular}{lcccc}
\hline \multicolumn{1}{c}{ Variable } & Constant and/or trend & Level & First difference & Inference \\
\hline Infl & Constant & -4.20 & $-7.05^{*}$ & $\mathrm{I}(1)$ \\
Infl & Constant and trend & -4.25 & $-7.11^{*}$ & $\mathrm{I}(1)$ \\
Gap & Constant & $-6.20^{*}$ & $-10.08^{*}$ & $\mathrm{I}(0)$ \\
Gap & Constant and trend & $-6.19^{*}$ & $-10.10^{*}$ & $\mathrm{I}(0)$ \\
Petrol & Constant & $-6.31^{*}$ & $-12.29^{*}$ & $\mathrm{I}(0)$ \\
Petrol & Constant and trend & $-6.25^{*}$ & $-12.24^{*}$ & $\mathrm{I}(0)$ \\
\hline * Denotes significance at 1 percent & & & \\
\hline
\end{tabular}

Table 5: ARDL co-integration tests with Bounds test results.

\begin{tabular}{cccccc}
\hline \multirow{2}{*}{$\begin{array}{c}\text { Dependent } \\
\text { variable }\end{array}$} & $\begin{array}{c}\text { Independent } \\
\text { variables }\end{array}$ & \multirow{2}{*}{$\begin{array}{c}\text { F statistic } \\
\text { (value) }\end{array}$} & \multicolumn{2}{c}{$99 \%$ critical bounds } & $\begin{array}{c}\text { Co-integration re- } \\
\text { sult }\end{array}$ \\
\hline$\Delta$ Infl & Gap, Petrol & 8.16 & 4.13 & 5.00 & Positive \\
\hline
\end{tabular}

Note: The null hypothesis for the F-test is $\beta_{1}=\beta_{2}=\beta_{3}=0$ where $\beta_{1}, \beta_{2}, \beta_{3}$ denotes the lagged coefficients as in Equation 2, and $\Delta$ is the difference operator. 
of the South African economy which began in the early 1990s was speeded up.

Panel B reflects the short-run impact of petrol inflation on headline inflation. The results show that the coefficient on the ECT is negative and statistically significant which confirms a valid short-run relationship among the variables with about 15 percent of the disequilibrium being corrected in each quarter. In the short-run, a 10 percent increase in petrol inflation results in headline inflation increasing by 0.6 percent with approximately half this increase becoming entrenched in the inflation process. This may be due to sticky price behaviour in the economy, which in effect means that some prices do not adjust downwards once they have increased. In other words, once non-petrol prices are adjusted upwards following an increase in petrol prices - so called second-round effects - they are sticky downwards. Finally, the diagnostic checks in panel $\mathrm{C}$ show that the results are robust. The LM test for autocorrelation rejected the null of no autocorrelation, testing for heteroscedasticity could not reject the assumption of homoscedasticity, the LM test could not reject the normality assumption and Ramsay's RESET test could not reject the fitted model.

Two additional issues of importance relate to the issue of asymmetry and the stability of the petrol price coefficient over time. Table 7 captures the asymmetry in the pass-through petrol price effects. The results indicate that the coefficient on price increases (Petrolpositive) is significant with a 10 percent increase resulting in a 1.2 percent increase in inflation over the long run. On the other hand, price declines (Petrolnegative) do not feed through in the long run indicating that prices are sticky downwards. The output gap (GAP) is also significant with the correct sign, implying that capacity constraints in the South African economy exert upward pressures on inflation

Table 6: Long-run and error correction estimates based on ARDL model.

\begin{tabular}{|c|c|c|}
\hline \multicolumn{3}{|c|}{ Panel A: Long-run coefficients based on Equation 5} \\
\hline Variables & Coefficient & $t$ statistic \\
\hline Gap & $0.79 *$ & 2.16 \\
\hline Petrol & $0.12 *$ & 2.41 \\
\hline Dummy & $-7.45^{+}$ & -7.36 \\
\hline constant & 12.03 & 12.49 \\
\hline
\end{tabular}

Panel B: Short-run coefficients based on Equation 6

\begin{tabular}{|c|c|c|}
\hline Variables & Coefficient & $t$ statistic \\
\hline $\mathrm{D}(\operatorname{Infl}(-1))$ & $0.38^{+}$ & 5.69 \\
\hline $\mathrm{D}($ Gap) & $-0.28 *$ & -2.52 \\
\hline $\mathrm{D}(\operatorname{Gap}(-1))$ & $0.24^{*}$ & 2.14 \\
\hline $\mathrm{D}($ Petrolinfl $)$ & $0.06^{+}$ & 7.52 \\
\hline $\mathrm{D}($ Petrolinfl $(-1))$ & $-0.03^{+}$ & -3.43 \\
\hline $\mathrm{D}($ dummy $)$ & $-3.09^{+}$ & -3.10 \\
\hline ECT & $-0.15^{+}$ & -5.48 \\
\hline Adj R2 & 0.95 & - \\
\hline D.W. stats & 2.03 & - \\
\hline F-Stats (prob) & $324.24(0.00)$ & - \\
\hline
\end{tabular}

Panel C: Diagnostic tests

\begin{tabular}{ll}
\hline Serial correlation: F-Stats (prob) & $0.19(0.82)$ \\
Functional form: F-Stats (prob) & $0.36(0.55)$ \\
Normality: $\chi^{2}$ (prob) & $3.32(0.19)$ \\
Heteroskedasticity: F-Stats (prob) & $2.34(0.02)$ \\
\hline
\end{tabular}

Notes: $\mathrm{D}$ denotes the first order difference operator. * and ${ }^{+}$denotes significance at the 5 percent and 1 percent levels respectively. In Panel C, the nulls are: (A) no serial correlation, (B) no functional-form misspecification, (C) no non-normal errors, and (D) no heteroskedasticity. 
Table 7: Long-run and error correction estimates based on ARDL model.

\begin{tabular}{|c|c|c|}
\hline \multicolumn{3}{|c|}{ Panel A: Long-run coefficients based on Equation 7} \\
\hline Variables & Coefficient & t statistic \\
\hline Gap & $0.85^{*}$ & 2.38 \\
\hline Petrolpositive & $0.12 *$ & 2.56 \\
\hline Petrolnegative & -0.04 & -0.26 \\
\hline Dummy & $-7.50^{+}$ & -7.60 \\
\hline constant & $11.70^{+}$ & 11.41 \\
\hline \multicolumn{3}{|c|}{ Panel A: Short-run coefficients based on Equation 8} \\
\hline $\mathrm{D}(\operatorname{Infl}(-1))$ & $0.38^{+}$ & 5.69 \\
\hline $\mathrm{D}$ (Gap) & $-0.28 *$ & -2.52 \\
\hline $\mathrm{D}(\mathrm{Gap}(-1))$ & $0.24^{*}$ & 2.14 \\
\hline $\mathrm{D}$ (Petrolpositive) & $0.06^{+}$ & 7.52 \\
\hline $\mathrm{D}($ Petrolpositive $(-1))$ & $-0.03^{+}$ & -3.43 \\
\hline $\mathrm{D}$ (Petrolnegative) & $0.05 *$ & 2.16 \\
\hline $\mathrm{D}$ (dummy) & $-3.09^{+}$ & -3.10 \\
\hline ECT & $-0.15^{+}$ & -5.48 \\
\hline Adj R2 & 0.95 & - \\
\hline D.W. stats & 2.03 & - \\
\hline F-Stats (prob) & $324.24(0.00)$ & - \\
\hline \multicolumn{3}{|c|}{ Panel C: Diagnostic tests } \\
\hline Serial correlation: F-St & & $0.25(0.78)$ \\
\hline Functional form: F-Stc & & $0.36(0.55)$ \\
\hline Normality: $\chi^{2}$ (prob) & & $0.25(0.62)$ \\
\hline Heteroskedasticity: F- $₫$ & & $2.27(0.02)$ \\
\hline
\end{tabular}

In order to ascertain the stability of the petrol price coefficient, the sample period is divided into two sub-periods, namely $1976 \mathrm{Q} 1$ to $1995 \mathrm{Q} 2$ and 1995Q3 to 2015Q4. This is done in light of earlier analysis that showed occurrence of a structural break in the series in 1995Q3. The long-run estimates are contained in Table 8.

As was the case previously, petrol price declines do not feed through to inflation over the long-run in both periods. On the other hand, petrol price increases feed through to inflation over both the periods. The coefficient on petrol price increases (petrolpositive) declined from around 0.19 to 0.14 . The decline in the pass-through coefficient is very much in line with the international experience as pointed out in Section 2. This in effect implies that a 10 percent increase in petrol prices currently results in headline inflation increase by about 1.4 percent as compared to 1.9 percent previously. These estimates can be used to ascertain the total contribution of petrol inflation to headline inflation during the sample period. The results are captured in Table 9 and indicate that the total contribution of petrol prices to headline inflation declined from about 2.6 percentage points (Jan76 to Jun95) to approximately 1.5 percentage points (Jul95 to Dec2015). The direct contribution of petrol price increases to inflation remained approximately at 0.5 percentage points, while the indirect contribution declined over two periods under analysis. It is, however, important to note that, despite the decline in the total contribution in terms of percentage points, the significant decrease in headline inflation over the sample period effectively resulted in the contribution of petrol price movements to headline inflation increasing from about 19 percent (Jan76 to Jun95) to approximately 24 percent (Jul95 to Dec2015). 
Table 8: Long-run estimates based on ARDL model.

\begin{tabular}{lcc}
\hline \multicolumn{1}{c}{ Variables } & Coefficient & t statistic \\
\hline Gap & $0.91^{*}$ & 2.28 \\
Petrolpositive & $0.19^{*}$ & 2.27 \\
Petrolnegative & -0.24 & -0.89 \\
Constant & $10.83^{+}$ & - \\
Adj R2 & 0.82 & - \\
D.W. stats & 1.79 & - \\
F-Stats (prob) & $44.92(0.00)$ & - \\
\hline \multicolumn{4}{c}{ Panel B: ARDL model for period 1995Q3 to 2015Q4 } \\
\hline Gap & $2.44^{*}$ & 3.41 \\
Petrolpositive & $0.14^{*}$ & 2.66 \\
Petrolnegative & 0.03 & 0.19 \\
constant & $3.91^{+}$ & 2.96 \\
Adj R2 & 0.87 & - \\
D.W. stats & 2.03 & - \\
F-Stats (prob) & 56.07 (0.00) & - \\
\hline Notes: D denotes the first order difference operator. *, denote significance at the 5 percent \\
and 1 percent levels respectively. In Panel C, the nulls are: (A) no serial correlation, (B) no \\
functional-form misspecification, (C) no non-normal errors, and (D) no heteroskedasticity. \\
\hline
\end{tabular}

Table 9: Direct, indirect and total contribution of petrol inflation to headline inflation.

\begin{tabular}{|c|c|c|}
\hline Parameter & $\begin{array}{c}\text { Jan } 1976 \text { to } \\
\text { June } 1995\end{array}$ & $\begin{array}{c}\text { July } 1995 \text { to } \\
\text { Dec } 1995\end{array}$ \\
\hline Headline inflation $^{1}$ & 13.33 & 6.07 \\
\hline Petrol inflation $^{2}$ & 13.83 & 10.63 \\
\hline Total contribution of petrol inflation to headline inflation ${ }^{3}$ & 2.63 & 1.49 \\
\hline Direct contribution of petrol inflation to headline inflation ${ }^{4}$ & 0.52 & 0.49 \\
\hline Indirect contribution of petrol inflation [(c)-(d)] & 1.91 & 1.00 \\
\hline \multicolumn{3}{|c|}{$\begin{array}{l}\text { Notes: } \\
\text { 1. Year-on-year change in the headline CPI. } \\
\text { 2. Year-on-year change in the petrol price index of the CPI. } \\
\text { 3. Petrol price pass-through coefficient of } 0.19 \text { (for period January } 1976 \text { to June 1995) and } 0.14 \text { (for period } \\
\text { July } 1995 \text { to December } 2015 \text { ) multiplied by petrol inflation. } \\
\text { 4. The average weight of petrol prices in the CPI multiplied by petrol inflation (b) for the specified periods. }\end{array}$} \\
\hline
\end{tabular}

\section{Some policy implications and areas for fur- ther research}

The empirical analysis in this paper has shown that the significance of petrol price movements for inflation outcomes in South Africa has increased over time. Petrol price movements accounted for approximately 24 percent of headline inflation during the period July 1995 to December 2015. The direct contribution of petrol inflation to headline inflation has exceeded its weight in the CPI. In addition, the analysis has shown that petrol prices have an important bearing on other (non-petrol) prices in the economy - stated differently petrol prices have strong second round price effects and are thus an important component of inflationary pressures in the economy. The CPI less food and energy (petrol) prices is conventionally regarded as an appropriate measure of core inflation or inflationary pressures in 
the economy. The exclusion of petrol prices is justified on the grounds that it is very volatile and is mean reverting over the long-run. However, excluding petrol prices from the core inflation measure is only justified if its long-run mean is equal to the core inflation measure. The argument here is that if the means are equal over the long-run then this implies that short-run fluctuations in the petrol price do not have a lasting impact on inflationary pressures.

Table 10 captures the results for the equality of means test between petrol and non-petrol inflation. The results indicate that the hypothesis of equality of means between petrol inflation and non-petrol inflation is rejected. This implies that petrol prices play a role in underpinning inflationary pressures in the South African economy. However, the official core inflation measure in South Africa excludes petrol prices - thus, the link between petrol inflation and inflationary pressures is much stronger than is assumed in policy circles in South Africa (see various monetary policy statements of the South African Reserve Bank). The role and significance of petrol price movements on core inflation measures in South Africa is an issue that warrants investigation. More specifically, further research that more systematically examines the influence of petrol price movements on inflation expectations and inflation dynamics could be very beneficial to policy formulation in South Africa.

Table 10: Equality of means test (StatsSA and own calculations).

\begin{tabular}{lcc}
\hline \multicolumn{1}{c}{ Method } & \multicolumn{2}{c}{$\begin{array}{c}\text { Petrol inflation and non-petrol } \\
\text { inflation (Jan 1976 to Dec 2015) }\end{array}$} \\
\cline { 2 - 3 } & Value & Probability \\
\hline t-test & 3.93 & 0 \\
Satterthwaite- & 3.93 & 0 \\
Welch t-test* & & \\
Anova F-test & 15.46 & 0 \\
Welch F-test* & 15.46 & 0 \\
\hline
\end{tabular}

As mentioned earlier, international factors account for approximately 60 percent of South Africa's fuel price. South Africa is a small open economy and hence is a price taker on the international market. However, the volatility and depreciation in the currency has had a significant on South Africa's fuel price trend. In a case where exchange rates are very volatile - fuel price-smoothing mechanisms could be used to cushion the adverse exchange rate impacts. Coady et al. (2012) provide an excellent analysis of fuel pricing mechanisms with price smoothing options that countries could consider to cushion the volatility in fuel price movements. The recommendations and options outlined by Coady et al. (2012) are worthy of consideration by the South African authorities.

An important area that has not been explored in this paper, but is worthy of further research, is the welfare implications of fuel price increases. Since the poor spend a larger portion of their income on transport costs, an issue of policy relevance is how fuel price increases impact on the economic welfare of the poor. The international experience related to transport subsidy reforms suggest that these should form part of a comprehensive strategy aimed at improving the overall efficiency of the transport sector (Anand et al., 2013). This issue is of particular relevance given reports that the government plans to overhaul the structure and manner in which public transport is subsidised in South Africa (Business Day, 2013).

\section{Conclusion}

The analyses of the impact of fuel price increases on inflation outcomes in South Africa since the mid1970s was carried out. The results show that petrol price movements had a significant bearing on inflation outcomes. The direct contribution of petrol inflation to headline inflation did not only increased but also exceeded its weight in the CPI over the last three and a half decades. In addition, the analysis showed that petrol prices have an important bearing on the prices of other (non-petrol) commodities in the economy. In short, petrol price increases had an important bearing on inflation outcomes in South Africa. Petrol price movements, therefore, warrant a special attention in policy formulation and implementation in South Africa if inflation outcomes were to be kept in check.

\section{References}

Álvarez, L., Hurtado, S., Sánchez, I., and Thomas, C. 2011. The impact of oil price changes on Spanish and Euro area consumer price inflation. Economic modelling 28: 422-431.

Barsky, R. and Kilian, L. 2001. Do we really know that oil caused the great stagflation: A monetary alternative (with comments). NBER Working paper 8289. National Bureau of Economic Research. Cambridge.

Bernanke, B., Gertler, M. and Watson, M. 1997. Systematic monetary policy and the effects of oil price shocks. Brookings papers on economic activity, economic studies program. The Brookings Institution 28: 91-157.

Blanchard, O. and Gali, J. 2010. The Macroeconomic effects of oil price shocks: Why are the 2000s different from the 1970s? In Gali, J and Gertler, M. (eds) International dimensions of monetary policy. University of Chicago Press, Chicago: 373-128.

Bruno, M. and Sachs, J. 1985. Economics of worldwide stagflation. Cambridge, Harvard University Press. Massachusetts. 
Bryan, M.F. and Cecchetti, S.G. 1993. Measuring core inflation. In Mankiw, G.N. (ed) Monetary policy. The University of Chicago Press. Chicago.

Burbidge, J. and Harrison, A. 1984. Testing for the effects of oil-price rise using vector autoregressions. International Economic Review 25: 459-484.

Business Day. 2013. ANC looks at 'subsidies for commuters. Available online at: http://www.bdlive.co.za/ business/transport/2013/08/29/anc-looks-at-subsidiesfor-commuters (Accessed on 7 April 2014).

Cecchetti, S. and Moessner, R. 2008. Commodity prices and inflation dynamics. BIS Working paper. Bank for International Settlement. Basel. Switzerland.

Chen, S. 2009. Oil price pass-through into inflation. Energy Economics 31: 126-33.

Clark, T. and Terry, S. 2010. Time variation in the inflation pass-through of energy prices. Journal of Money, Credit and Banking 42: 1419-1433.

Coady, D, Javier, A., Eyraud, L., Jin, H., Thakoor, V., Tuladhar, A. and Nemeth, L. 2012. Automatic fuel pricing mechanisms with price smoothing: Design, implementation, and fiscal implications. Technical notes and manual. Fiscal Affairs Department, International Monetary Fund, Washington.

Competition Tribunal. 2006. In the Competition Tribunal of South Africa, Competition Tribunal Case No 101/LM/Dec04. Competition Tribunal. South Africa. Available online at: http://www.comptrib.co.za/assets/Uploads/Case-Documents/101LMDec04.pdf . Accessed on 12 March 2014

De Gregorio, J., Landerretche, O. and Neilson, C. 2007. Another pass-through bites the dust? Oil prices and inflation. Economía 7: 155-208.

Erol, U. and Yu, E.S.H. 1987. On the relationship between electricity and income for industrialised countries. Journal of Electricity and Employment 13: 113-122.

Gisser, M. and Goodwin, T. 1986. Crude oil and the macroeconomy: Tests of some popular notions: Note. Journal of Money, Credit and Banking 18: 95103.

Habermeier, K., Ötker-Robe, I., Jacome, L., Giustiniani, A., Ishi, K., Vavra, D., Kişinbay, T. and Vázquez, T. 2009. Inflation pressures and monetary policy options in emerging and developing countries: A cross regional perspective. IMF Working Paper 09/01. International Monetary Fund, Washington.

Hamilton, J. 1983. Oil and the macroeconomy since world War II. Journal of Political Economy. 91: 228248.

Hamilton, J. 1988. A neoclassical model of unemployment and the business cycle. Journal of Political Economy 96: 593-617.

Hooker, M. 2002. Are oil shocks inflationary? Asymmetric and nonlinear specifications versus changes in regime. Journal of Money, Credit and Banking 34: 540-561.

Independent online. 2014. Petrol price hike adds to woes. Available online at: http://www.iol.co.za/ news/south-africa/petrol-price-hike-adds-to-woes1.1641980_(Accessed on 1 April 2014.)
International Monetary Fund. 2008. World Economic Outlook. International Monetary Fund, Washington. October.

Kilian, L. 2008. The economic effects of energy price shocks. Journal of Economic Literature 46: 871-909.

Leblanc, M and Chinn, M. 2004. Do high oil prices presage inflation? The evidence from G5 countries. Working paper no 561. University of California Santa Cruz.

Lilien, D. 1982. Sectoral shifts and cyclical unemployment. Journal of Political Economy 90: 777-793.

Mork, K. 1989. Oil and the macroeconomy When prices go up and down: An extension of Hamilton's results. Journal of Political Economy 97: 740-744.

Mork, K. 1994. Business cycles and the oil market. The Energy Journal 15: 15-38.

Narayan, P. K. 2005). The saving and investment nexus for China: Evidence from co-integration tests. Applied Economics 37: 1979-1990.

Pedersen, M. 2011. Propagation of shocks to food and energy prices: An international comparison. Central Bank of Chile working paper no 648. Central Bank of Chile, Santiago, Chile.

Pesaran, M. H. Shin, Y. and Smith, R.J. 2001. Bounds testing approaches to the analysis of level relationships. Journal of Applied Econometrics 16: 289-326.

Rahul, A. Coady, D., Mohommad, A. Thakoor, V. and Walsh, J.P. 2013. The fiscal and welfare impacts of reforming fuel subsidies in India. Working paper, WP/13/128. International Monetary Fund, Washington.

Rigobon, R. 2010. Commodity prices pass-through, Central Bank of Chile Working Paper No. 572. Central Bank of Chile, Santiago, Chile.

Trehan, B. 2005. Oil price shocks and inflation. Economic Letters 28: 1-3.

Zoli, E. 2009. Commodity price volatility, cyclical fluctuations, and convergence: What is ahead for inflation in emerging Europe? IMF Working Paper 09/41. International Monetary Fund, Washington. 